\title{
First report of Curvularia eragrostidis causing fruit rot in Hylocereus undatus in India
}

\author{
Daliyamol $^{1} \cdot$ VH Prathibha ${ }^{1} \cdot$ Vinayaka Hegde $^{1} \cdot$ G Panjavarnam $^{1}$
}

Received: 9 April 2021 / Accepted: 1 October 2021 / Published online: 26 October 2021

(c) Società Italiana di Patologia Vegetale (S.I.Pa.V.) 2021

Keywords Coconut $\cdot$ Fruit rot $\cdot$ C. eragrostidis

During 2019, a severe fruit rot disease with $15-20 \%$ incidence was noticed in nightblooming cactus (Hylocereus undatus (Haw.) Britton \& Rose) grown as inter crop in coconut gardens in Kasaragod, Kerala (India). The symptoms included water-soaked, olive to black powdery spots coalescing to form large lesions leading to soft rotting of the entire pink fleshed fruits. Curvularia strains were consistently isolated from infected tissues by following standard tissue isolation method. Subsequently, the pathogen was purified through single spore isolation technique (Choi et al. 1999). The culture were characterized by grey-white mycelial colonies with radial growth that later turned to olive black on both surface of the potato dextrose agar (PDA). Microscopic observations revealed light brown septate conidiophores present singly or in groups, straight or curved, up to $250 \mu \mathrm{m}$ long and $6 \mu \mathrm{m}$ wide having geniculate growth pattern near the apex region. The conidia are ellipsoidal or barrel shaped with 22-25 $\mu \mathrm{m}$ length and $10-13 \mu \mathrm{m}$ width. Based on these morphological characters, the fungus was identified as Curvularia eragrostidis (Henn.) J.A. Mey (Ellis 1971). To confirm the morphological identification, the internal transcribed spacer (ITS) rDNA and Glyceraldehyde 3-phosphate dehydrogenase (GAPDH) gene regions of the reference isolate were amplified and sequenced. BLAST analysis of the sequences (GenBank accession Nos. for ITS sequence MN890020 and for GAPDH MW587754) showed $100 \%$ and $99 \%$, respectively, with available sequences of C. eragrostidis (KT933675 and LT715827). Pathogenicity of the fungus was tested on healthy nightblooming cactus. Three $\mu \mathrm{l}$ of fresh conidial suspension $\left(1 \times 10^{7} \mathrm{cfu} / \mathrm{ml}\right)$ were inoculated to the fruit using pin prick method and incubated at $26 \pm 1{ }^{\circ} \mathrm{C}$. As a control, nightblooming cactus fruits were

Daliyamol

dmo186@gmail.com

1 Division of Crop Protection, ICAR-Central Plantation Crops Research Institute, Kasaragod 671 124, Kerala, India inoculated with plain agar discs and sterile water. Five days post inoculation, dark lesions appeared on the fruits exactly similar to that appeared in the field, but not in controls. Koch's postulates were confirmed by reisolation of C. eragrostidis from the symptomatic nightblooming cactus. The fungal isolate was sent to National Fungal Culture Collection of India (NFCCI) Pune for identification confirmation and submitted with NFCCI accession number 4905 . To our knowledge, this is the first report of fruit rot caused by $C$. eragrostidis on nightblooming cactus in India and worldwide (Farr and Rossman 2021).

Funding ICAR-Central Plantation Crops Research Institute (1000765039).

\section{Declarations}

Ethical approval This article does not contain any studies with human participants or animals performed by any of the authors.

Conflict of interest Authors declares that no conflict of interest.

\section{Reference:}

Choi YW, Hyde KD, Ho WH (1999) Single spore isolation of fungi. Fungal Divers 3:29-38

Ellis MB (1971) Dematiaceous hypomycetes. Commonwealth Mycological Institute, Kew, pp 452- 459

Farr DF, Rossman AY (2021) Fungal Databases, U.S. National Fungus Collections, ARS, USDA

Publisher's Note Springer Nature remains neutral with regard to jurisdictional claims in published maps and institutional affiliations. 